\title{
Satisfaction on the university frontline services: From the lens of transacting students and employees
}

\author{
Marivic A. Gorospe ${ }^{1}$, Ma. Angelita S. Rabanal ${ }^{2}$, Arlene D. Talosa ${ }^{3}$ \\ ${ }^{1}$ Graduate School, Cagayan State University, Philippines \\ ${ }^{2,3}$ Graduate School and College of Teacher Education, Cagayan State University, Philippines
}

\begin{tabular}{l}
\hline Article Info \\
\hline Article history: \\
Received Feb 3, 2021 \\
Revised Jul 6, 2021 \\
Accepted Jul 17, 2021 \\
\hline
\end{tabular}

Keywords:

Academic satisfaction

Employees

Frontline

Services

Students

\begin{abstract}
Client satisfaction is an influential predictor of academic life, such as services delivered with suitable standards. Thus, the study focused on determining the level of client satisfaction on the frontline services of Cagayan State University in Aparri, Philippines from the perspective of students and employees. To assess suitability, relevance, and to ensure adequate and reliable information for the evaluation of the study, the researchers adopted the descriptive- evaluative design and ascertained the level of clients' satisfaction on the frontline services received and experienced on the campus. The study, however, was limited to the assessment of the respondents on their level of contentment only on the frontline services and providers they have encountered. The results indicated a very high level of satisfaction with which heads of offices have gained higher satisfaction ratings than that of their staff. When grouped according to the respondents' profile, the older students rated higher the frontline services and providers than the younger ones. At the same time, regular employees have a higher level of satisfaction as compared to non-regular. The result of the study manifests students' and employees' very high contentment with the actual performances of the frontline service providers.
\end{abstract}

This is an open access article under the CC BY-SA license.

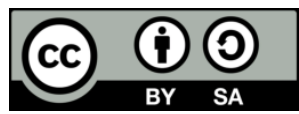

\section{Corresponding Author:}

Ma. Angelita S. Rabanal

Graduate School and College of Teacher Education

Cagayan State University

CSU Aparri Compound, Maura, Aparri, Cagayan, 3515, Philippines

Email: angiesrabanal@gmail.com; arabanal@csu.edu.ph

\section{INTRODUCTION}

Institutions of higher education as the rudimentary provider of both academic and non-academic services to their clients [1], client satisfaction on their frontline services is the most imperative asset they may have. It is the main driver for performance and relies heavily on frontline service habits [2]. Consequently, recognizing that these frontline services providers are conceivably the most critical link in delivering quality educational services, there has been increasing attention rendered to client satisfaction regarding the quality of service delivery [3]. Motefakker [4] argues that it is necessary that viewpoints, tastes, and desires of transacting clients be completely taken into consideration. Given the importance to the idea that students are clients or customers of higher education institutions emphasize their rights and the duty of the institutions to deliver the finest educational services possible [5] and eventually leads to the creation of their sense of belonging and loyalty to the university, and not only does it create a sense of satisfaction but makes them feel to be a member of the organization. This satisfaction is key to the success of a university [4]. 
In terms of marketing, customer satisfaction is the degree to which a product or service meets or exceeds the standards of consumers [6]. In order to reach the satisfaction of consumers, organizations launch customer-friendly and comprehensive management approaches [7]. In the race to win consumers' (i.e., students and employees') preferences retain sustainable competitive advantages and global competition has emphasized the importance of value, worth, and satisfaction. Quality, satisfaction, and success prove to be the core factors reciprocally interrelated in a cyclical relationship as educational programs evolve into services for people.

Customers are more pleased when service quality is high. As a result, educational institutions and universities put a greater focus on fulfilling the desires and needs of their clients, the "students," in order to attract new customers [8]. Poor service quality contributes to losing an average of $12 \%$ of the customers [9]. Service quality and program quality are critical factors for developing and sustaining relationships with customers [10]. Since it has a significant impact on customer satisfaction and customer loyalty to service providers, this construct is a key determinant of the organization's success or failure in a competitive environment [11]. The gap between consumers' perceptions of a specific institution's services and their expectations for such services is known as service quality [12]. Many stakeholders and their concerns, whether educational or social, illustrate the value of such a service. It's important to have a qualityimprovement plan in place. The demand is higher, not just in terms of teaching efficiency, but also in terms of social standards.

Aside from the prime mandate of providing instruction, research and extension to the public, government higher education institutions are indispensable instruments in providing service quality to clients [13]. An accomplishment of any institution relies on the competence of fore employees as they are considered the main characters to build the first and lasting impressions towards an organization's positive image to its clients [14]. La Viña [15] in 2012 stated that "public office is not a vehicle for personal aggrandizement, nor is it a license for abuse; public office is not a private property, but one impressed with public accountability." It is on this principle that each government worker must always put in his heart and mind that to be working for the government is a sacrifice of oneself for the sake of the country.

Along this line, Section 2 of R.A. 6713 (Code of Conduct and Ethical Standards for Public Officials and Employees) provides, "It is the policy of the State to promote a high standard of ethics in public service. Public officials and employees shall at all times be accountable to the people and shall discharge their duties with utmost responsibility, integrity, competence, and loyalty, act with patriotism and justice, lead modest lives, and uphold the public interest over personal interest."

The increasing interest in recognizing and responding to clients' interactions with service delivery is reflected in the extensive literature on client satisfaction in social services and various attempts to implement concrete steps [16]. Customer satisfaction is primarily dictated by the interactions of the customers during the transaction, which is why service quality is such an essential component of satisfaction. The quality or state of the service determines the type of performance the provider is able to deliver to the customers [17].

Hanaysha and Kumar [18] established that service quality and satisfaction has a significant correlation. Student motivation, educational satisfaction, and enjoyment at their place of education are all important factors in an educational institution's progress. It is therefore important to retain high educational quality in order to evaluate the condition of students' well-being and boost academic standards [19]. Hence, the conduct of this client satisfaction survey will give the university realistic and potential feedback on the actual performance of its frontline services.

\section{RESEARCH METHOD}

To assess suitability and relevance, and to ensure adequate and reliable information for the evaluation of the study, the researchers adopted the descriptive-evaluative design and ascertained the level of clients' satisfaction on the frontline services received and experienced in the campus. Descriptive as the study determined the profile of respondents and the weighted mean of their level of satisfaction received and experience on the frontline services of the campus. Evaluative, on the other hand, compared significant differences in the mean responses of the respondents when grouped according to respondents' profile, type of clientele, frontline service provider evaluated, and frontline service office assessed.

To reduce the impact of confounding variables, respondents were chosen in random. The profile variables were also chosen such that they are relevant and matching to the major variable of the study, ensuring that there is no multi-collinearity between them.

The researchers used the university-made structured students and faculty and personnel satisfaction survey questionnaire for collecting data in determining the level of clients' satisfaction on the frontline services experienced and received on the campus. The questionnaire included two parts. Part 1 aimed to gather general information of the respondents relevant to the study, such as age, sex, and college, or office of 
the respondent. Part 2 dealt with the respondents' assessment of their level of satisfaction with the different frontline services availed. The face and content validity of the questionnaire underwent evaluation of experts of the field while reliability coefficient of the questionnaire was found to be 0.80 which means it is reliable.

The respondents of the study as shown in Table 1 were the employees (faculty, personnel) regardless of their employment status and bonafide students enrolled during the evaluation period. The total enumeration of those present during the conduct of the survey was employed to further improve the validity and reliability of the study.

Table 1. Respondents of the study

\begin{tabular}{|c|c|c|c|}
\hline & & Population & Respondents \\
\hline \multirow{9}{*}{$\begin{array}{c}\text { Nature of } \\
\text { students }\end{array}$} & College of Hospitality Management & 653 & 566 \\
\hline & College of Information and Computing Sciences & 513 & 417 \\
\hline & College of Business, Entrepreneurship, and Accountancy & 376 & 344 \\
\hline & College of Teacher Education & 289 & 266 \\
\hline & College of Criminal Justice Education & 250 & 211 \\
\hline & College of Industrial Technology & 223 & 187 \\
\hline & College of Fisheries and Aquatic Sciences & 144 & 128 \\
\hline & Graduate School & 104 & 14 \\
\hline & Total & 2552 & 2133 \\
\hline \multirow{3}{*}{$\begin{array}{l}\text { Nature of } \\
\text { employees }\end{array}$} & Faculty & 84 & 68 \\
\hline & Personnel & 71 & 64 \\
\hline & Total & 155 & 132 \\
\hline
\end{tabular}

The researchers secured written permission from the head of the campus to float the questionnaires to the target students and employees' respondents. After the approval of the permit has been sought, the researchers administered the questionnaire to the target respondents. Before the data was collected, the participants were given written instructions and informed of their right to refuse participation in the study. Informed consent included general directions, research details, aim, and confidentiality agreements for each participant. After the questionnaires were retrieved, the researchers tabulated, processed, and analyzed the data manually and by machine.

Descriptive statistical tools and frequency counts provide a comprehensive description of the demographic profile of the stakeholder-respondents. Weighted arithmetic mean was used to measure the respondents' level of satisfaction with the frontline services received and experienced. The t-test and analysis of variance determine significant differences between these levels when grouped according to respondents' profile and type of respondents. Relative hereto, the researchers used the $0.5 \%$ level of significance in testing all hypotheses in the study. The level of student satisfaction's responses in the questionnaire was scored, classified, and given interpretations as in Table 2.

Table 2. Scoring interpretation

\begin{tabular}{cccl}
\hline Score & Scoring interval & Interpretation & \multicolumn{1}{c}{ Meaning } \\
\hline 4 & $3.20-4.00$ & Very satisfied & Manifests high contentment of the actual performance of the services \\
3 & $2.40-3.19$ & Satisfied & Manifests contentment \\
2 & $1.60-2.39$ & Less satisfied & Manifests less contentment \\
1 & $1.00-1.59$ & Least satisfied & Manifests a very little contentment \\
\hline
\end{tabular}

\section{RESULTS AND DISCUSSION}

\subsection{Profile of the student respondents}

Table 3 shows the profile of the students. In terms of their age, the table reveals that $956(44.8 \%)$ of them belong to the age range 19 to $20 ; 821(38.5 \%)$ of them belong to the age ranges 17 to $18 ; 312(14.6 \%)$ of them belong to the age ranges 21 to $22 ; 30(1.4 \%)$ of them belong to the age ranges 23 to $24 ; 14(0.7 \%)$ of them belong to age ranges 25 or above. The mean age is 19.20 , with a standard deviation of 1.76 . This finding means that most of the student respondents are from the first year, which composed the majority of enrolment on the campus due to the K-12 transition.

In terms of their sex, the table reveals that $1241(58.2 \%)$ of the students are female; and $892(41.8 \%)$ of them are male. In terms of the college where they belong, it reveals $566(26.5 \%)$ of them belong to the College of Hospitality Management; 417 (19.5\%) of them belong to the College of Information and Computing Sciences; 344 (16.1\%) belong to the College of Business, Entrepreneurship, and Accountancy; $266(12.5 \%)$ of them belong to the College of Teacher Education; 211 (9.9\%) of them belong to the College of Criminal Justice and Administration; 187 (8.8\%) of them belong to the College of Industrial Technology; 
$128(6.0 \%)$ of them belong to the College of Fisheries and Marine Sciences; $14(0.7 \%)$ of them belong to Graduate School. This finding means that the highest enrolment comes from the Hospitality Industry Management and the Information and Computing Sciences in that order.

Table 3. Profile of the students

\begin{tabular}{llcc}
\hline \multicolumn{1}{c}{ Variables } & Frequency $(\mathrm{n}=2133)$ & Percentage \\
\hline Age (in years) & 25 or above & 14 & 0.7 \\
& 23 to 24 & 30 & 1.4 \\
& 21 to 22 & 312 & 14.6 \\
& 19 to 20 & 956 & 44.8 \\
& 17 to 18 & 821 & 38.5 \\
Sex & Mean (S.D.) & $19-20$ years $(1.76)$ \\
College & Female & 1241 & 58.2 \\
& Male & 892 & 41.8 \\
& College of Hospitality Management & 566 & 26.5 \\
& College of Information and Computing Science & 417 & 19.5 \\
& College of Business Entrepreneurship Accountancy & 344 & 16.1 \\
& College of Teacher Education & 266 & 12.5 \\
& College of Criminal Justice Education & 211 & 9.9 \\
College of Industrial Technology & 187 & 8.8 \\
& College of Fisheries and Aquatic Sciences & 128 & 6.0 \\
Graduate School & 14 & 0.7 \\
\hline
\end{tabular}

\subsection{Profile of the employee respondents}

Table 4 presents the profile distribution of the employee comprising faculty and personnel. The faculty respondents in terms of age reveal that 15 (22.1\%) of them belong to ages 59 to 65 and 24 to 30 , respectively; $12(17.6 \%)$ of them belong to the age range 29 to $65 ; 11(16.2 \%)$ of them belong to the age range 38 to $44 ; 10(14.7 \%)$ of them belong to the age range 31 to $37 ; 5(7.4 \%)$ of them belong to the age range 45 to 51 . The mean age is 44.31 , with a standard deviation of 12.43 .

Table 4. Profile of the employees

\begin{tabular}{cccccc}
\hline \multirow{2}{*}{ Variables } & & \multicolumn{2}{c}{ Faculty } & \multicolumn{2}{c}{ Personnel } \\
& & $\mathrm{f}(\mathrm{n}=68)$ & $\%$ & $\mathrm{f}(\mathrm{n}=64)$ & $\%$ \\
\hline Age (in years) & 59 to 65 & 12 & 17.6 & 10 & 15.6 \\
& 52 to 58 & 15 & 22.1 & 17 & 26.6 \\
& 45 to 51 & 5 & 7.4 & 4 & 6.3 \\
& 38 to 44 & 11 & 16.2 & 8 & 12.5 \\
\multirow{5}{*}{ Sex } & 31 to 37 & 10 & 14.7 & 10 & 15.6 \\
& 24 to 30 & 15 & 22.1 & 15 & 23.4 \\
Employment status & Mean (S.D.) & 44.31 years $(12.43)$ & 44.39 years $(13.23)$ \\
& Female & 42 & 61.8 & 24 & 37.5 \\
& Male & 26 & 38.2 & 40 & 62.5 \\
& Regular & 61 & 89.7 & 40 & 62.5 \\
& Part-time & 7 & 10.3 & - & - \\
& Contract of service & - & - & 13 & 20.3 \\
& Job order & - & - & 11 & 17.2 \\
\hline
\end{tabular}

The personnel respondents in terms of age reveal that $17(26.6 \%)$ of them belong to the age range 52 to $58 ; 15(23.4 \%)$ of them belong to the age range 24 to $30 ; 10(15.6 \%)$ of them belong to the age range 59 to 65 and 31 to 37 respectively; eight $(12.5 \%)$ of them belong to the age range 38 to 44 ; four $(6.3 \%)$ of them belong to the age range 45 to 51 . The mean age is 44.30 , with a standard deviation of 13.23 . This finding reveals that more or less there is a normal distribution of employees in terms of age. Regarding the data of the faculty- employee respondents in terms of their sex, the table reveals that $42(61.8 \%)$ of them are female and $26(38.2 \%)$ are male. Meanwhile, male personnel respondents comprise $40(62.5 \%)$ while $24(37.5 \%)$.

Finally, employment status reveals that $61(89.7 \%)$ of them are regular; and seven $(10.3 \%)$ of them are part-time. The personnel respondents in terms of employment status disclose that $40(62.5 \%)$ of them are regular; $13(20.3 \%)$ of them are a contact of service; and $11(17.2 \%)$ of them are job order. This finding indicates that most of the respondents are tenured.

\subsection{Level of satisfaction on the frontline services received and experienced by the students}

Table 5 shows the level of satisfaction of the students on the frontline services they received and experienced. Registrar Services earned a satisfaction rating of 3.51, Library Services is 3.60, Student 
Development and Welfare Services is 3.61, Guidance Services is 3.66, Accounting Services is 3.57, Cashiering Services is 3.57, Medical and Dental Services is 3.70, Business Services is 3.51, Socio-cultural Services is 3.60, Sports Services is 3.58 and Admission Services is 3.59. The overall weighted mean of the summary of the level of satisfaction of the students on the frontline services they received and experienced is 3.59 with a descriptive value of "very high". The finding indicates that the respondents are very satisfied with the services offered and received in the different frontline services.

This finding implies that the offices create a working environment for highly satisfied customers with their office service performance. On the same manner, satisfaction with academic services is a measure of the success of higher education performance in providing education [20].

Table 5. Summary of the level of satisfaction of the students on the frontline services they received and experienced

\begin{tabular}{lcccccc}
\multicolumn{1}{c}{ Frontline offices } & \multicolumn{2}{c}{ Head of office } & \multicolumn{2}{c}{ Staff } & \multicolumn{2}{c}{ Total } \\
& WM & DV & WM & DV & WM & DV \\
\hline Registrar services & 3.57 & VH & 3.46 & VH & 3.51 & VH \\
Library services & 3.63 & VH & 3.57 & VH & 3.60 & VH \\
Student development and welfare services & 3.65 & VH & 3.57 & VH & 3.61 & VH \\
Guidance services & 3.69 & VH & 3.63 & VH & 3.66 & VH \\
Accounting services & 3.60 & VH & 3.53 & VH & 3.57 & VH \\
Cashiering services & 3.61 & VH & 3.53 & VH & 3.57 & VH \\
Medical and dental services & 3.72 & VH & 3.68 & VH & 3.70 & VH \\
Business services & 3.54 & VH & 3.48 & VH & 3.51 & VH \\
Socio-cultural services & 3.63 & VH & 3.57 & VH & 3.60 & VH \\
Sports services & 3.61 & VH & 3.55 & VH & 3.58 & VH \\
Admission services & 3.62 & VH & 3.55 & VH & 3.59 & VH \\
\multicolumn{1}{c}{ Overall mean } & 3.62 & Very high & 3.56 & Very high & 3.59 & Very high \\
\hline
\end{tabular}

\subsection{Level of satisfaction on the frontline services received and experienced by employees}

Table 6 shows the level of satisfaction of the employees on the frontline services they received and experienced. All frontline offices were rated very high. Specifically, the overall weighted mean of the level of satisfaction of the employees on the frontline services they received and experienced from the Registrar's Office is 3.93 with a descriptive value of "very high". An interview revealed that services to employees by the registrar include submission of grades, production of employees ID's, and others aside from the transcript of records of alumni of this campus. The level of satisfaction of the employees on the frontline services they received and experienced from the Campus Library is 3.94 with a descriptive value of "very high". The researchers found out that the employees used the library for their readings during their vacant hours. Further, the library is very conducive and houses a variety of library holdings. The overall weighted mean of the level of satisfaction of the employees on the frontline services they received and experienced from the Accounting Office is 3.96 with a descriptive value of "very high". This finding may be a result of the professionalism and competence of the accounting staff in its services to the employees. Its services are vital to the employees in the processing of their salaries, benefits, and others.

Table 6. Summary of the level of satisfaction of the employees on the frontline services they received and experienced

\begin{tabular}{ccccccc}
\hline \multirow{2}{*}{ Frontline offices } & \multicolumn{2}{c}{ Head of office } & \multicolumn{2}{c}{ Staff } & \multicolumn{2}{c}{ Total } \\
& WM & DV & WM & DV & WM & DV \\
\hline Registrar services & 3.95 & VH & 3.91 & VH & 3.93 & VH \\
Library services & 3.97 & VH & 3.91 & VH & 3.94 & VH \\
Accounting services & 3.97 & VH & 3.95 & VH & 3.96 & VH \\
Cashiering services & 3.99 & VH & 3.95 & VH & 3.97 & VH \\
Medical-dental services & 3.96 & VH & 3.95 & VH & 3.96 & VH \\
Human resources services & 3.96 & VH & 3.94 & VH & 3.95 & VH \\
Records services & 3.98 & VH & 3.95 & VH & 3.96 & VH \\
Supply services & 3.93 & VH & 3.90 & VH & 3.92 & VH \\
Overall mean & 3.96 & Very high & 3.93 & Very high & 3.95 & Very high \\
\hline 3.25-4.00>>Very high; 2.50-3.24>>High; 1.75-2.49>>Low; 1.00-1.74>>Very low
\end{tabular}

The overall weighted mean of the level of satisfaction of the employees on the frontline services they received and experienced from the Cashier's Office is 3.97 with a descriptive value of "very high". Cashiering services to employees include payment of salaries and other benefits or claims of employees. The fact that the campus uses Automated Teller Machines as a conduit for these claims and benefits greatly 
enhanced the customer satisfaction of this frontline service. The overall weighted mean of the level of satisfaction of the employees on the frontline services they received and experienced from the Medical and Dental Clinic and Records Office is 3.96 with a descriptive value of "very high". Also, the Human Resources Office is 3.95 with a descriptive value of "very high." Meanwhile, the overall weighted mean of the level of satisfaction of the employees on the frontline services they received and experienced from the Supply Office is 3.92 with a descriptive value of "very high".

This finding implies that all frontline offices of Cagayan State University at Aparri are wellperforming and fostering educational quality services. They were all rated very high in terms of client satisfaction. Itani, et al. [21] posited that frontline providers need to adapt most of their service behaviors to match customers' demands. Such findings also uphold Santos, et al. [22] results that an approach to fostering a responsible university impacts the positive attitudes and functions of students as a precedent of service quality and customer satisfaction.

\subsection{Comparison tests on the level of satisfaction of the respondents on the frontline services 3.5.1. Grouped according to students' profile}

The study hypothesized that there is no significant difference in the level of satisfaction on the services of the frontline offices when grouped according to their profile. It is apparent in Table 7 that a significant comparison exists between the above 19 years old and 19 years old or below, as revealed by the tvalue of 6.603 with a probability of 0.000 . These findings mean that students ages 19 and above rate the services higher than the younger ones. These findings corroborate with the results of the study by Sivanandamoorthy [23] that age, education, and income of respondents have a substantial effect on the perception of customer satisfaction.

In terms of sex, there is no significant comparison exist in female and male as reveal by the t-value of 0.724 with a probability of 0.469 . Non-significance of perception of sex was also observed in the study of Deshwal [24], where a statistically significant difference between perceptions of female and male respondents was not found. On the other hand, it disputes the results of the study of Bhat and Darzi [25], showing that there is a difference in satisfaction across gender where male customers have higher expectations than female customers. As to college, it is apparent in the table that a significant comparison exists between groups and within groups as revealed by the f-ratio of 26.114 with a probability of 0.000 .

Table 8 reveals the significant comparison of the student's level of satisfaction on the services of the frontline offices when grouped according to their college. It is apparent in the table that a significant comparison exists in the between groups and within groups as reveal by the f-ratio of 26.114 with a probability of 0.000 .

Table 7. Comparison of the students' level of satisfaction with the services of the frontline offices when grouped according to their profile

\begin{tabular}{lcccccc}
\hline Groups & & Mean & S.D. & t-value & Prob. & Statistical inference \\
\hline Age $^{1}$ & Above 19 years old & 3.53 & 0.33 & \multirow{2}{*}{6.603} & \multirow{2}{*}{0.000} & \multirow{2}{*}{ Significant } \\
& 19 years old or below & 3.63 & 0.30 & & & \multirow{2}{*}{ Sex } \\
Female & 3.59 & 0.31 & \multirow{2}{*}{0.724} & \multirow{2}{*}{0.469} & \multirow{2}{*}{ Not significant } \\
& Male & 3.60 & 0.32 & & &
\end{tabular}

${ }^{1}$ Above or below the average age of the students;

Tested at 0.05 level of significance using t-test for independent samples

Table 8. Comparison of the students' level of satisfaction on the services of the frontline offices when grouped according to their colleges

\begin{tabular}{|c|c|c|c|c|c|c|c|c|c|}
\hline & \multicolumn{2}{|c|}{ Sum of squares } & df & \multicolumn{2}{|c|}{ Mean square } & F-ratio & Prob. & \multicolumn{2}{|c|}{ Statistical inference } \\
\hline Between groups & & 5.621 & 7 & \multicolumn{2}{|c|}{2.374} & 26.114 & 0.000 & \multicolumn{2}{|c|}{ Significant } \\
\hline Within groups & & 3.224 & 2125 & \multirow{2}{*}{\multicolumn{2}{|c|}{0.091}} & & & & \\
\hline Total & & 9.845 & 2132 & & & & & & \\
\hline \multicolumn{10}{|c|}{ Post-hoc analysis using LSD } \\
\hline \multirow{2}{*}{ Colleges } & \multirow{2}{*}{ Mean } & \multirow{2}{*}{ S.D. } & \multicolumn{7}{|c|}{ Crosstabs of mean differences (*significantly different) } \\
\hline & & & GS & CFAS & CTE & CIT & CBEA & CCJE & CICS \\
\hline GS & 3.99 & 0.01 & - & & & & & & \\
\hline CFAS & 3.73 & 0.26 & $0.266^{*}$ & - & & & & & \\
\hline CTE & 3.72 & 0.26 & $0.273^{*}$ & 0.007 & - & & & & \\
\hline CIT & 3.68 & 0.30 & $0.313^{*}$ & 0.047 & 0.039 & - & & & \\
\hline CBEA & 3.63 & 0.32 & $0.367 *$ & $0.101 *$ & $0.094 *$ & $0.054 *$ & - & & \\
\hline CCJE & 3.59 & 0.28 & $0.406^{*}$ & $0.140 *$ & $0.133^{*}$ & $0.093^{*}$ & 0.039 & - & \\
\hline CICS & 3.52 & 0.30 & $0.474 *$ & $0.208 *$ & $0.200 *$ & $0.161^{*}$ & $0.107 *$ & $0.068 *$ & - \\
\hline CHIM & 3.51 & 0.33 & $0.482 *$ & $0.216^{*}$ & $0.208^{*}$ & $0.169 *$ & $0.115^{*}$ & $0.076^{*}$ & 0.008 \\
\hline
\end{tabular}




\subsubsection{Grouped according to employees' profile}

Table 9 reveals the significant comparison of the employee's level of satisfaction with the services of the frontline offices when grouped according to their profile. It is apparent in the table that a significant comparison exists in the regular and non-regular (Part-time, COS, JO) as revealed by the t-value of 2.451 with a probability of 0.019 . But in terms of age and sex, there is no significant comparison as shown by the $t$ value of 1.885 and 0.265 with a probability of 0.062 and 0.792 . This finding means that regular employees who enjoy all privileges offered by the university have a higher level of satisfaction compared to non-regular employees. This contradicts Matsuki and Nakamura [26], in terms of the effects of various sub-factors on satisfaction, and no significant differences were found by employment pattern.

Table 9. Comparison of the employees' level of satisfaction on the services of the frontline offices when grouped according to their profile

\begin{tabular}{ccccccc}
\hline Groups & & Mean & S.D. & t-value & Prob. & Statistical inference \\
\hline Age $^{1}$ & 44 years old or above & 3.92 & 0.17 & \multirow{2}{*}{1.885} & \multirow{2}{*}{0.062} & \multirow{2}{*}{ Not significant } \\
& Below 44 years old & 3.96 & 0.12 & & & \multirow{2}{*}{ Not significant } \\
Sex & Female & 3.94 & 0.14 & \multirow{2}{*}{0.265} & 0.792 & \multirow{2}{*}{ Significant } \\
& Male & 3.94 & 0.15 & & & \multirow{2}{*}{0.019} \\
\hline
\end{tabular}

${ }^{1}$ Above or below the average age of the employees

${ }^{2}$ Regular employees have permanent position who enjoy all privileges offered by the university

Tested at 0.05 level of significance using t-test for independent samples

\subsubsection{Grouped according to group of respondents}

Table 10 reveals the significant comparison of the respondent's level of satisfaction with the services of the frontline offices. It is apparent in the table that a significant comparison exists between groups and within groups as revealed by the f-ratio of 77.489 with a probability of 0.000 . As disclosed in Table 10 that there is a significant difference as reckoned with a probability of 0.357 and 0.332 .

Table 10. Comparison of the respondents' level of satisfaction with the services of the frontline offices

\begin{tabular}{|c|c|c|c|c|c|c|}
\hline & Sum of squares & df & Mean square & F-ratio & Prob. & Statistical inference \\
\hline Between groups & 14.572 & 2 & 7.286 & 77.489 & 0.000 & Significant \\
\hline Within groups & 212.684 & 2262 & 0.094 & & & \\
\hline Total & 227.255 & 2264 & & & & \\
\hline \multicolumn{7}{|c|}{ Post-hoc analysis using LSD } \\
\hline \multirow{2}{*}{ Respondents } & \multirow{2}{*}{ Mean } & \multirow{2}{*}{ S.D. } & \multicolumn{4}{|c|}{ Crosstabs of mean differences (*significantly different) } \\
\hline & & & Perso & & & Faculty \\
\hline Personnel & 3.95 & 0.16 & - & & & \\
\hline Faculty & 3.93 & 0.13 & 0.0 & & & - \\
\hline Students & 3.60 & 0.31 & 0.35 & & & $0.332 *$ \\
\hline
\end{tabular}

Tested at 0.05 level of significance using one-way analysis of variance

\subsubsection{Grouped as head of office or staff}

The comparison of the respondent's level of satisfaction towards the head of the office and staff of the frontline offices is shown in Table 11. There is a significant comparison that exists in registrar, library, accounting, cashier, medical and dental, student development and welfare, guidance, business, socio-cultural, sports, and admission services. In human resources, records, and supply services, there is no significant comparison with the probability of $0.423,0.107$, and 0.349 because these three offices are not day by day visited offices. These results were also noted in the study of Jalali, et al. [27] student expectation upsurges as they do increase transactions with the university services.

The study reveals that the satisfaction rating of the head of the office is significantly higher than their staff in many offices. The researchers found out that the heads of the offices are highly educated and more trained than their staff. Thus, heads of offices are more likely those holding regular positions. According to Sabir, et al. [28] in their study, satisfied employees have a pronounced impact on customer satisfaction and must be taken as extremely important because they represent the organization to the public. Similarly, non-teaching personnel's kindness and academic staff individual attention were positively related with students' satisfaction [29]. Consequently, factors such as skilled and competent personnel, polite and welcoming workers, and fast and better service quality can all help to improve client satisfaction [30]. 
Table 11. Comparison of the respondents' level of satisfaction towards the head of office and staff of the frontline offices

\begin{tabular}{|c|c|c|c|c|c|c|}
\hline \multicolumn{2}{|l|}{ Groups } & \multirow{2}{*}{$\frac{\text { Mean }}{3.60}$} & \multirow{2}{*}{$\frac{\text { S.D. }}{0.42}$} & \multirow{2}{*}{$\frac{t \text {-value }}{8.445}$} & \multirow{2}{*}{$\frac{\text { Prob. }}{0.000}$} & \multirow{2}{*}{$\frac{\text { Statistical inference }}{\text { Significant }}$} \\
\hline Registrar services & Head of office & & & & & \\
\hline & Staff & 3.48 & 0.46 & & & \\
\hline \multirow[t]{2}{*}{ Library services } & Head of office & 3.66 & 0.37 & 5.142 & 0.000 & Significant \\
\hline & Staff & 3.59 & 0.40 & & & \\
\hline \multirow[t]{2}{*}{ Accounting services } & Head of office & 3.63 & 0.41 & 4.866 & 0.000 & Significant \\
\hline & Staff & 3.56 & 0.42 & & & \\
\hline \multirow[t]{2}{*}{ Cashier services } & Head of office & 3.64 & 0.41 & 6.123 & 0.000 & Significant \\
\hline & Staff & 3.56 & 0.43 & & & \\
\hline \multirow[t]{2}{*}{ Medical and dental services } & Head of office & 3.73 & 0.34 & 3.048 & 0.002 & Significant \\
\hline & Staff & 3.69 & 0.37 & & & \\
\hline \multirow[t]{2}{*}{ Student devt. and welfare services } & Head of office & 3.65 & 0.38 & 6.487 & 0.000 & Significant \\
\hline & Staff & 3.57 & 0.40 & & & \\
\hline \multirow[t]{2}{*}{ Guidance services } & Head of office & 3.69 & 0.36 & 4.548 & 0.000 & Significant \\
\hline & Staff & 3.63 & 0.38 & & & \\
\hline \multirow[t]{2}{*}{ Business services } & Head of office & 3.54 & 0.44 & 3.628 & 0.000 & Significant \\
\hline & Staff & 3.48 & 0.46 & & & \\
\hline \multirow[t]{2}{*}{ Socio-cultural services } & Head of office & 3.63 & 0.40 & 4.166 & 0.000 & Significant \\
\hline & Staff & 3.57 & 0.42 & & & \\
\hline \multirow[t]{2}{*}{ Sports services } & Head of office & 3.61 & 0.43 & 3.540 & 0.000 & Significant \\
\hline & Staff & 3.55 & 0.45 & & & \\
\hline \multirow[t]{2}{*}{ Admission services } & Head of office & 3.62 & 0.41 & 3.962 & 0.000 & Significant \\
\hline & Staff & 3.55 & 0.41 & & & \\
\hline \multirow[t]{2}{*}{ Human resources services } & Head of office & 3.96 & 0.16 & 0.804 & 0.423 & Not significant \\
\hline & Staff & 3.94 & 0.19 & & & \\
\hline \multirow[t]{2}{*}{ Records services } & Head of office & 3.98 & 0.10 & 1.619 & 0.107 & Not significant \\
\hline & Staff & 3.95 & 0.22 & & & \\
\hline \multirow[t]{2}{*}{ Supply services } & Head of office & 3.93 & 0.22 & 0.939 & 0.349 & Not significant \\
\hline & Staff & 3.90 & 0.25 & & & \\
\hline
\end{tabular}

\subsection{Educational implication}

The result of the study manifests students' and employees' high satisfaction with the institution's frontline service providers. With this, the administration showcases academic support quality with its transacting clients. The very high client satisfaction is an influential predictor of educational life, such as implicit services, explicit services, and physical services delivered with suitable standards. As such, as a higher education institution committed to transforming lives, the institution should strengthen its practices. Administratively, the results challenge the service providers of the campus in terms of sustainability, the same in the context of the new normal.

\section{CONCLUSION}

In light of the following findings, the researchers conclude that students and employees of the Cagayan State University at Aparri, Philippines had a very high level of satisfaction in all the frontline services of the campus. The head of offices have a higher satisfaction rating than that of their staff.

The campus should sustain its best practices on frontline service delivery to keep the very high level of satisfaction of the frontline service offices. To further validate the findings of the study, it must be replicated considering guests/visitors who avail of services from the frontline offices. A similar study in the whole university should be undertaken and find out if there is a significant relationship between the client satisfaction of the performance of the campuses in the attainment of its targets in PBB and other indicators.

\section{REFERENCES}

[1] E. Y. Ali, M. Munir, J. Permana, and D. A. Kurniady, "Improving the quality of academic services in higher education by the development of SIMANTAP," Universal Journal of Educational Research, vol. 8, no. 2, pp. 371-386, 2020.

[2] Y.-C. Lee, Y.-C. Wang, S.-C. Lu, Y.-F. Hsieh, C.-H. Chien, S.-B. Tsai, and W. Dong, "An empirical research on customer satisfaction study: a consideration of different levels of performance,” SprinerPlus, vol. 5, p. 1577, 2016.

[3] M. K. Brady, C. J. Robertson, and J. J. Cronin, "Managing behavioral intentions in diverse cultural environments: an investigation of service quality, service value, and satisfaction for American and Ecuadorian fast-food customers," Journal of International Management, vol. 7, no. 2, pp. 129-149, 2001. 
[4] N. Motefakker, "The Study of the Level of Satisfaction of the Students of the Faculty of Social Sciences with Welfare Services of Imam Khomeini International University of Qazvin," Procedia Economics and Finance, vol. 36, pp. 399-407, 2016.

[5] J. P. Royo, "Students as customers: a paradigm shift in higher education," Debats. Journal on Culture, Power and Society, vol. 131, no. 3, pp. 137-149, 2017.

[6] H. Iberahim, N. M. Taufik, A. M. Adzmir, and H. Saharuddin, "Customer satisfaction on reliability and responsiveness of self service technology for retail banking services," Procedia Economics and Finance, vol. 37, pp. 13-20, 2016.

[7] K. F. Adrutdin, A. A. Ali, S. H. Hassan, J. Jaafar, N. S. A. Rahim, and M. I. Qureshi, "The Relationship between Knowledge for Customer and Service Quality on Customer Satisfaction: A Study on UniKL MITEC Student Services," International Journal of Engineering and Technology, vol. 7, no. 2.29, pp. 69-72, 2018.

[8] S. Thomas, "What Drives Student Loyalty in Universities: An Empirical Model from India," International Business Research, vol. 4, no. 2, pp. 183-192, 2011.

[9] K. Riscinto-Kozub, "The Effects of Service Recovery Satisfaction on Customer Loyalty and Future Behavioral Intentions: An Exploratory Study in the Luxury Hotel Industry," Auburn University Electronic Theses and Dissertation, 2008.

[10] A. R. Osman, R. S. Saputra, and J. Saha, "Determinants of student satisfaction in the context of higher education: a complete structural equation modeling approach," British Journal of Marketing Studies, vol. 5, no. 6, pp. 1-14, 2017.

[11] S.-P. Lin, Y.-H. Chan and M.-C. Tsai, "A transformation function corresponding to IPA and gap analysis," Total Quality Management and Business Excellence, vol. 20, no. 8, pp. 829-846, 2009.

[12] P.-F. Chou, C.-S. Lu and Y.-H. Chang, "Effects of service quality and customer satisfaction on customer loyalty in high-speed rail services in Taiwan," Transportmetrica A: Transport Science, vol. 10, no. 10, pp. 917-945, 2014.

[13] B. Sapitula, "The role of Philippine state colleges and universities in enhancing food security," Journal of International Society for Southeast Asian Agricultural Sciences, vol. 18, pp. 18-21, 2012.

[14] A. H. Mengesha, "Effects of marketing competency of frontline employees on customer satisfaction: A study on commercial bank of Ethiopia," AshEse Journal of Business Management, vol. 1, no. 4, pp. 39-50, 2015.

[15] T. La Viña, "Public office, public trust," Manila Standard Today, Philippines, 2012.

[16] C. L. Mundy, A. N. Neufeld and S. J. Wells, "A culturally relevant measure of client satisfaction in child welfare services," Children and Youth Services Review, vol. 170, pp. 177-189, 2016.

[17] G. Mamo, "Assessment of the Factors that Affect Customer Satisfaction on Service Quality: A Case Study in Ethio Telecom Dawro Zone,” Arabian Journal of Business and Management Review, vol. 8, no. 1, 2018.

[18] J. R. M. Hanaysha, K. M. Dileep and O. Y. Abdullah, "Service quality and satisfaction: Study on international students in universities of North Malaysia," International Journal of Research in Management, vol. 3, no. 2, pp. 116-133, 2012.

[19] R. E. Demirbatır, "Comparison of burnout, vigor and education satisfaction of music and art majors in department of fine arts education," International Journal of Evaluation and Research in Education (IJERE), vol. 9, no. 3, pp. 478-485, 2020.

[20] Kuswanto and I. Anderson, "Effect of service quality and motivation on the consumption behavior of students in the academic services of University of Jambi," International Journal of Evaluation and Research in Education (IJERE), vol. 10, no. 1, pp. 86-96, 2021.

[21] O. S. Itani, F. Jaramillo and B. Paesbrugghe, "Between a rock and a hard place: Seizing the opportunity of demanding customers by means of frontline service behaviors," Journal of Retailing and Consumer Services, vol. 23, 2020, doi: 10.1016/j.jretconser.2019.101978.

[22] G. Santos, C. S. Marques, E. Justino and L. Mendes, "Understanding social responsibility's influence on service quality and student satisfaction in higher education," Journal of Cleaner Production, vol. 256, May 2020.

[23] S. Sivanandamoorthy and M. Karunanithy, "Personal Demographical Factors and their Influence on Customer Satisfaction from Customer Perspective," European Journal of Business and Management, vol. 5, no. 20, pp. 42-45, 2013.

[24] S. Deshwal, "Impact of Gender on Customer Satisfaction for Service Quality: A Case Study of Hyper Stores," International Journal of Multidisciplinary Research and Development, vol. 8, no. 2, pp. 596-599, 2015.

[25] S. A. Bhat and M. A. Darzi, "Exploring the role of gender on customer satisfaction: A customer relationship perspective from the banking sector," The Business Review, vol. 18, no. 1, pp. 44-51, 2014.

[26] T. Matsuki and J. Nakamura, "Effect of Employees' Values on Employee Satisfaction in Japanese Retail and Service Industries," Advances in Human-Computer Interaction, vol. 2019, pp. 1-11, 2019.

[27] A. Jalali, M. A. Islam and K. H. K. Ariffin, "Service Satisfaction: The Case of a Higher Learning Institution in Malaysia,” International Education Studies, vol. 4, no. 1, pp. 182-192, 2011.

[28] R. Sabir, N. Akhtar, S. Aziz, B. Sarwar, S. Zulfiqar and M. Irfan, "Impact of Employee Satisfaction on Customer Satisfaction: A Study of Lahore Electric Supply Company of Pakistan," Journal of Basic and Applied Scientific Research, vol. 4, pp. 229-235, 2014.

[29] V. Krishnamoorthy, A. Aishwaryadevi and B. Bharathi, "An Examination of Influence of Higher Education Service Quality on Students' Satisfaction: An Indian Perspective,” Indira Management Review, vol. 10, no. 2, pp. 96-102, 2016.

[30] M. G. Perez and L. S. Ilagan, "Clients' Satisfaction on the Frontline Services of a Government Higher Education Institution,” European Journal of Education Studies, vol. 6, no. 9, pp. 361-385, 2019. 